\title{
Physical and physiological aspects of gear efficiency in North Sea brown shrimp fisheries
}

\author{
R. Berghahn ${ }^{1}$, K. Wiese ${ }^{2}$ \& K. Lüdemann ${ }^{1}$ \\ ${ }^{1}$ Institut für Hydrobiologie und Fischereiwissenschaft der Universität Hamburg, \\ Elbelabor; Große Elbstraße 268, 22767 Hamburg, Germany \\ ${ }^{2}$ Zoologisches Institut und Zoologisches Museum der Universität Hamburg; \\ Martin-Luther-King-Platz 3, 20146 Hamburg, Germany
}

\begin{abstract}
In search of means to reduce the by-catch of juvenile flatfish in the shrimp fishery, vibrations and changes in current velocity caused by shrimp trawls were investigated in the field and in the laboratory. Buried as well as emerged shrimps (Crangon crangon) exhibit tailflips $5-10 \mathrm{~cm}$ before being touched by the rollers of a shrimp gear approaching them at a speed of $0.5 \mathrm{~m} \cdot \mathrm{sec}^{-1}$, as was revealed by slow motion video recordings in aquaria under artificial light. Hence, the signal effective in triggering escape must be attenuated strongly with increasing distance. Sediment vibration, commonly assumed to be an important signal in triggering escape of shrimps, was found to decrease by a factor $100 \cdot \mathrm{m}^{-1}$. Signals from the rollers of a commercial shrimp gear in operation (towing speed $1 \mathrm{~m} \cdot \mathrm{sec}^{-1}$ ) were directly recorded with an accelerometer. Their frequency ranged from 50 to $500 \mathrm{~Hz}$ and reached an acceleration of $40 \mathrm{~m} \cdot \mathrm{sec}^{-2}$ on soft bottom or up to $100 \mathrm{~m} \cdot \mathrm{sec}^{-2}$ on hard substrate. Accelerometers, which had been buried right at the surface of a tidal sand flat during low tide, produced only one sharp signal of $100 \mathrm{~Hz}$ with an acceleration of $24 \mathrm{~m} \cdot \mathrm{sec}^{-2}$, when a shrimp gear swept them on the submerged tidal flats. However, in aquaria short sinusoidal signals $\left(<5 \mathrm{~m} \cdot \mathrm{sec}^{-2} ; 20\right.$ to $300 \mathrm{~Hz}$ ) made buried shrimps and flatfish (Pleuronectes platessa, Solea solea, Microstomus kitt) hide rather than flee. The vibrations recorded directly at the rollers and the underlying jolting movements of the rollers induce corresponding pulses in the water surrounding the rollers in a layer of approximately $10-15 \mathrm{~cm}$. Similar water displacement of high acceleration was experimentally produced by a spring loaded transparent lucite piston ( $7 \mathrm{~cm}$ in diameter) fitted to an accelerometer. Accelerating this piston $\left(12-116 \mathrm{~m} \cdot \mathrm{sec}^{-2}, 50-200 \mathrm{~Hz}\right.$ range) from $5 \mathrm{~cm}$ above towards the shrimp produced escape responses in up to $94 \%$ of the tests. Arthropods are known to perceive medium displacement rather than pressure. Hence, strong and rapidly rising water currents caused by the rollers rather than sediment vibration are assumed to mainly trigger the escape reaction, which makes Crangon accessible to the gear.
\end{abstract}

\section{INTRODUCTION}

Brown shrimp (Crangon crangon L.) fisheries in the coastal waters of the North Sea contribute to deaths and injuries of juvenile fish (Tiews, 1983; Berghahn et al., 1992; Lüdemann, 1993). The present design of the gear has been developed by the fishermen during the last decades according to their day-to-day experience with regard to shrimp catches. Fishermen believe that the rollers of the ground rope used by the shrimp trawlers cause sediment vibrations which make buried shrimps emerge from the sediment.

Recently, increasing attention is being concentrated on the reduction of by-catch in the shrimp fishery (Berghahn, 1993). Along the coast, shrimping is carried out in waters of 
high turbidity. Catches are positively correlated with turbidity and adversely affected by light. This points to visual detectability of the gear which may highly influence the catch regardless of whether the animals are buried or emerged. Consequently, gear efficiency of shrimp trawls for $C$. crangon, as well as for unwanted by-catch such as juvenile fish, cannot realistically be determined by means of video recordings only. Information on the sensory capacity and the physiological control of escape in both shrimps and potential bycatch organisms is essential for improving the selectivity of the fishing method. Escape response in Procambarus has been a focus in neurophysiological research for a long time (Wine \& Krasne, 1982). However, the results from the laboratory, as well as from other crustacean species, cannot directly be transferred to Crangon or to fish species. In order to close this gap of knowledge, the following experiments were carried out.

\section{MATERIAL AND METHODS}

Animals were kept in aerated 100-l tanks at ambient temperatures for a few days. Only specimens, which had survived the catch virtually unhurt were selected for the experiments. Artificial seawater (INSTANT OCEAN ) was used. The bottom of the tanks was covered with a 2-cm layer of sand. Chopped meat of mussel or fish was provided in excess every second day.

\section{Experiment 1: Shrimp behaviour in front of approaching gear}

40 shrimps ( 5.0 to $6.5 \mathrm{~cm}$ in length) were placed on the sand bottom of an aquarium $\left(2.5 \times 0.5 \mathrm{~m} ; \mathrm{S}=25, \mathrm{~T}=15^{\circ} \mathrm{C}\right.$, light: Osram L36 $30 \mathrm{~W}$, Warmton, at a distance of $\left.1.0 \mathrm{~m}\right)$ and given 15 min to adapt. Then a single roller of a commercial shrimp gear (rubber disk, $20 \mathrm{~cm}$ in diameter, width $10 \mathrm{~cm}$, weight $6.6 \mathrm{~kg}, 2.5 \mathrm{~kg}$ in water) was pulled with a nylon string from one side of the basin to the other at a speed of $0.5 \mathrm{~m} \cdot \mathrm{sec}^{-1}$ (approximately $1 \mathrm{knot})$. The escape reaction of the animals was recorded on video tape.

\section{Experiment 2: Shrimp reaction to water pulses}

Shrimps were placed individually in 10 circular cages in separate 10-1 aquaria (18.5 $\times 28.5 \mathrm{~cm}$, water depth $11 \mathrm{~cm}, \mathrm{~S}=30, \mathrm{~T}=15^{\circ} \mathrm{C}$, light: Osram L36 $30 \mathrm{~W}$, Warmton, at a distance of $1.0 \mathrm{~m}$; Fig. 1). A circular transparent disk $(7 \mathrm{~cm}$ diameter) mounted to the end of a transparent rod was thrust from a distance of $10 \mathrm{~cm}$ in a fast and short $(3-5 \mathrm{~cm})$ pulse towards each specimen. Trials were also conducted with a non-transparent disk. The acceleration of the disk was measured with an accelerometer (Bruel \& Kjær type 8319) attached to the device. The response of the shrimps was noted. After a series of 10 specimens had been treated, they were replaced by 10 fresh ones from the stock tank, which were given $1 \mathrm{~min}$ to adapt.

\section{Experiment 3: Sensitivity of shrimp and flatfish to sediment vibration}

Sensitivity to vibration of the sea bottom was studied using the following setup (Fig. 2): a transparent plastic bag filled with $0.5 \mathrm{~kg}$ sand and $0.5 \mathrm{~kg}$ seawater from the aquarium was put onto the membrane of a passive loudspeaker attached to an electro- 


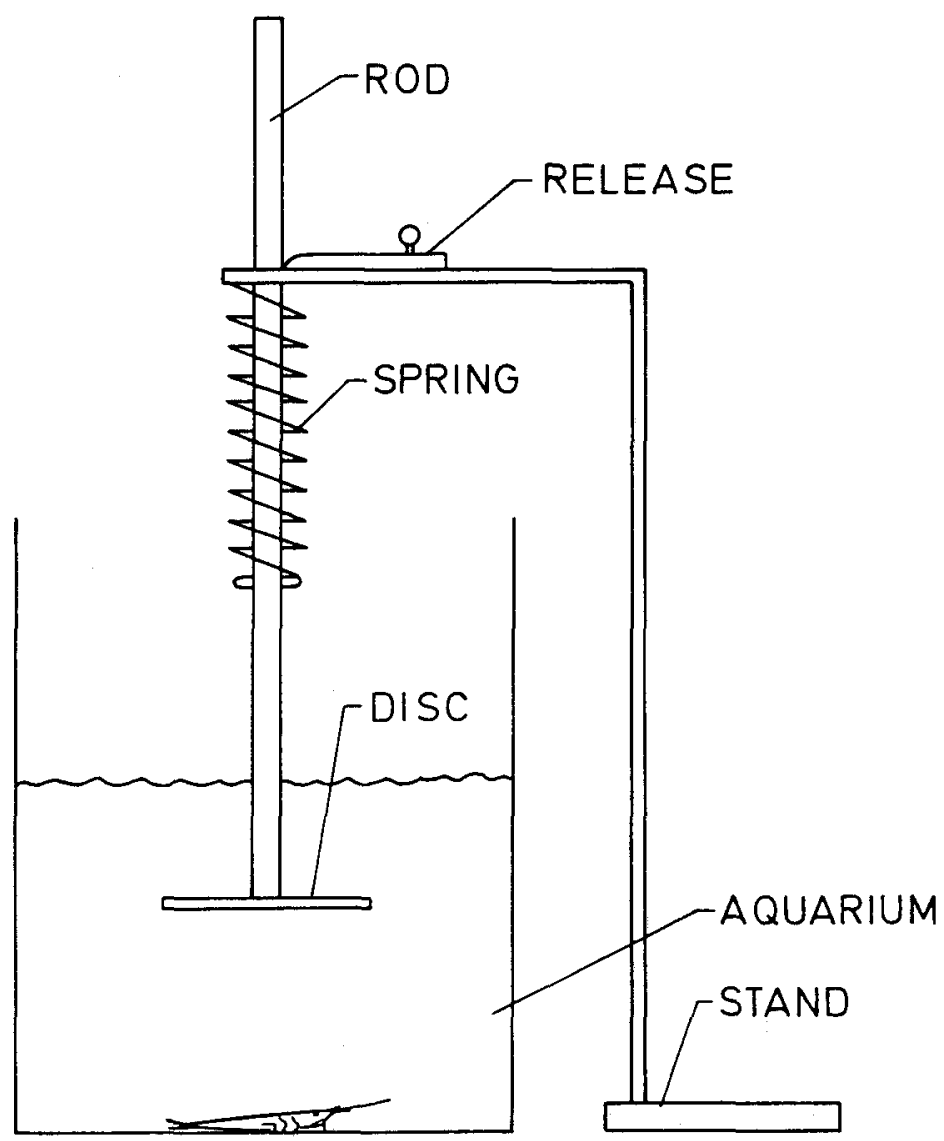

Fig. 1. Experimental set-up for testing reaction of shrimp to water pulses

dynamic vibrator (Bruel \& Kjær Mini-Shaker type 4810) at its centre (cf. Heinisch \& Wiese [1987]). The shaker performed sinusoidal oscillations at clearly defined frequencies provided by a function generator (Impo FD 13.07). Onset of the stimulus, pulse width, pulse duration and amplitude could be precisely adjusted employing an additional device. Accelerations actually occurring in the sand were recorded by means of an accelerometer (Bruel \& Kjær type 4338) directly mounted on the shaker. The signal was amplified by means of a microphone power supply (Bruel \& Kjær type 2804) and displayed for measurement on an oscilloscope (Kikusui COS 5020). Since the plastic bag was suspended from an adjustable boom, pure sinusoidal oscillations could easily be achieved at any given frequency.

Specimen were tested by transferring them individually into the bag. Adaptation time was $15 \mathrm{~min}$. Usually, animals submerged into the sand during this period. At each frequency and each amplitude tested, stimuli were presented in 3 sequential trials at a pulse duration of $600 \mathrm{~ms}$. Interstimulus then was $10 \mathrm{sec}$. Under artificial light conditions IOsram L $36 \mathrm{~W} / 30$, Warmton, distance $2 \mathrm{~m}$ ), a clearly defined response could be recorded 


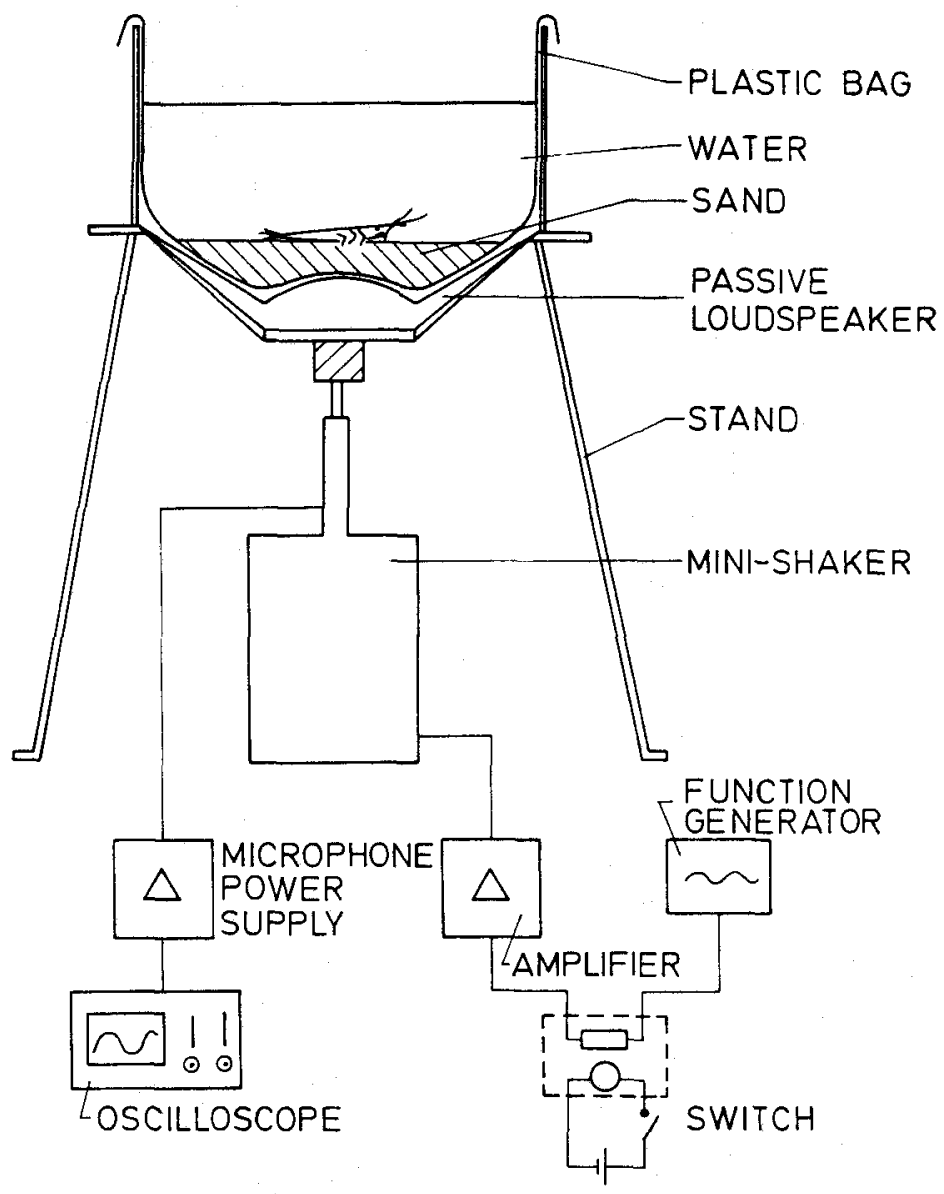

Fig. 2. Experimental set-up for testing sensitivity of shrimp and flatfish to sediment vibration

for each species. A stimulus was considered subthreshold if the animal failed to respond immediately in at least 2 out of 3 sequential trials. Experiments were run with an interstimulus of $3 \mathrm{~min}$ for a maximum duration of $1 \mathrm{~h}$ per animal and day. In some cases, experiments had to be concluded earlier due to habituation. The experiments were conducted with 8 plaice (Pleuronectes platessa L.), 6 shrimps, 2 soles (Solea solea L.) and a lemon sole (Microstomus kitt Walb.) at $20^{\circ} \mathrm{C}$. Four specimens of plaice were also tested at $16^{\circ} \mathrm{C}$.

\section{Experiment 4: Gear and sediment vibration in the field}

Two accelerometers (see Expenment 2) were tightly connected with a steel plate $(37 \times 3 \times 0.4 \mathrm{~cm} ; 400 \mathrm{~g})$ and buried at a distance of $1 \mathrm{~m}$ on a tidal sand flat during low tide. Accelerations were produced by an automatic hammer mill which was put into use on the submerged tidal flats right beside the first accelerometer. Their damping was measured at a distance of $1 \mathrm{~m}$ by comparison with the second accelerometer. Then the 
area was repeatedly swept with a commercial shrimp trawl. The accelerometer signals were amplified with a "Line Drive Supply, Brüel \& Kjær 2813", recorded with a "Racal Thermionic Ltd. 4D" tape recorder which was based on an anchored boat besides the track, and analysed later on a "Real-Time Audiospectrum Analyser, Hewlett Packard $8064 \mathrm{~A}^{\prime \prime}$ in the laboratory. Moreover, an accelerometer was attached to the axis of one of the rollers in operation and the signals recorded on the shrimp vessel (Fig. 3).

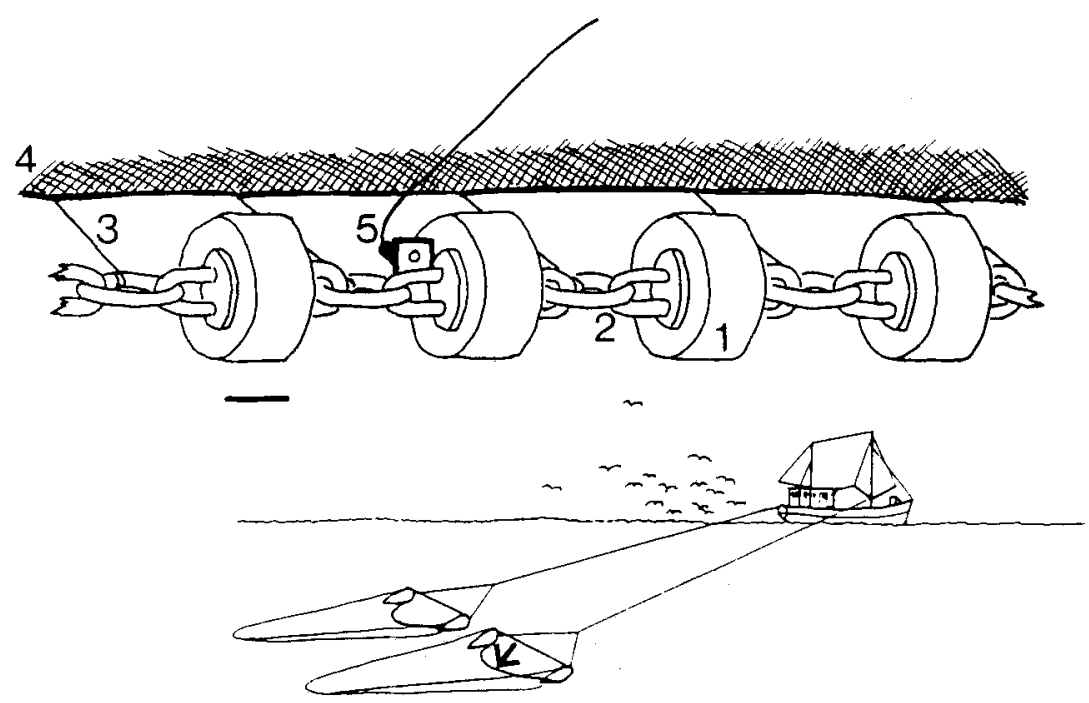

Fig. 3. Accelerometer attached to a roller of the groundrope of a commercial shrimp gear. Arrow indicates the part of the gear for the close up. $1=$ rubber disc; $2=$ steel mountings; $3=$ line to ground rope; $4=$ ground rope and net; $5=$ steel plate with accelerometer. $B a r=10 \mathrm{~cm}$

\section{RESULTS \\ Experiment 1: Shrimp behaviour in front of approaching gear}

Buried as well as emerged shrimps exhibit tailflips well before being touched by the rollers of an approaching shrimp gear, as was revealed by slow motion video recordings under artificial light in aquaria. The direction of the approach was not important. The specimens already emerged $5-10 \mathrm{~cm}$ before the rollers. Habituation was considerable at 5 min intervals.

\section{Experiment 2: Shrimp reaction to water pulses}

The transparent disk proved to be less effective at inducing escape reactions than the visible version (Table 1). Tailflips could be induced in both emerged and buried specimens. Buried small specimens of $4 \mathrm{~cm}$ could be stimulated more easily than specimens of about $6 \mathrm{~cm}$. Small specimens which had become buried and were treated by this method lost their sand cover by the accompanying spray of sand and exhibited escape responses. Habituation was considerable. 
Table 1. Response of shrimps to water pulses

\begin{tabular}{|c|c|c|c|c|c|}
\hline $\begin{array}{l}\text { Tension } \\
\text { of spring }\end{array}$ & $\begin{array}{c}\text { Max. accelera- } \\
\text { tion of disc } \\
{\left[\mathrm{m} \cdot \mathrm{sec}^{-2}\right]}\end{array}$ & $\begin{array}{l}\text { Angle of } \\
\text { pulse }\left[^{\circ}\right]\end{array}$ & $n$ & $\begin{array}{l}\text { Number of } \\
\text { tail-flipping } \\
\text { specimens }\end{array}$ & $\begin{array}{l}\% \text { tail-flipping } \\
\text { specimens }\end{array}$ \\
\hline \multicolumn{6}{|c|}{ Disc visible, no sediment: } \\
\hline 4 & 116 & 90 & 20 & 14 & 70 \\
\hline 3 & 72 & 90 & 11 & 10 & 91 \\
\hline 2 & 42 & 90 & 19 & 14 & 74 \\
\hline 1 & 32 & 90 & 17 & 15 & 88 \\
\hline Free fall & 38 & 90 & 34 & 32 & 94 \\
\hline Free fall (damped) & 12 & 90 & 42 & 38 & 90 \\
\hline 4 & 116 & 45 & 19 & 12 & 63 \\
\hline \multicolumn{6}{|c|}{ Disc transparent, no sediment: } \\
\hline Free fall (damped) & 32 & 90 & 30 & 11 & 37 \\
\hline $\begin{array}{l}\text { Tension } \\
\text { (damped) }\end{array}$ & 68 & 90 & 49 & 34 & 69 \\
\hline \multicolumn{6}{|c|}{ Disc transparent, specimens buried in sand: } \\
\hline $3+1+2$ & 72 & 90 & 30 & 12 & 40 \\
\hline
\end{tabular}

\section{Experiment 3: Sensitivity of shrimp and flatfish to sediment vibration}

Shrimps responded to sediment vibration with movements of their large second antennae. Plaice responded with one extra movement of the operculum. In contrast, one specimen of sole stopped its gill ventilation for a second, whereas the second specimen's reaction was similar to that of plaice. The lemon sole tested displayed a quick turn of its eyes.

The lowest threshold of perception for vibration of sand or water was $40 \mathrm{~cm} \cdot \mathrm{sec}^{-2}$ $(20-200 \mathrm{~Hz})$ in shrimps, and slightly lower in flatfish. Sensitivity to sediment vibration was about the same in shrimp and flatfish. It was greatest in sole $\left(10 \mathrm{~cm} \cdot \mathrm{sec}^{-2}\right.$ at 20 to $170 \mathrm{~Hz}$ ). At low frequencies the difference from the other species was ten times greater. Thresholds of response in plaice were similar to those in lemon sole and were lowest between 100 and $200 \mathrm{~Hz}$ (Fig. 4). At frequencies between 20 and $100 \mathrm{~Hz}$, thresholds decreased in warmer water. Shrimps were a little more sensitive at low frequencies compared to trials from $140 \mathrm{~Hz}$ upwards (Fig. 4). When pulse width was enlarged from $600 \mathrm{~ms}$ to $3000 \mathrm{~ms}$, the threshold in shrimp was lower. At frequencies higher than $300 \mathrm{~Hz}$, sensitivity decreased drastically in both shrimp and flatfish. At all frequencies tested, even very strong accelerations (e.g. $200 \mathrm{~m} \cdot \sec ^{-2}$ at $200 \mathrm{~Hz}$ ) did not induce buried specimens, whether shrimps or flatfish, to emerge from the sand.

\section{Experiment 4: Gear, water and sediment vibration in the field}

The signal produced by the hammer mill was damped to $1 / 100$ at a distance of $1 \mathrm{~m}$. Signals from the rollers of a commercial shrimp gear in operation, which were directly recorded with an accelerometer, ranged from 50 to $500 \mathrm{~Hz}$ (Fig. 5) and reached $40 \mathrm{~m}$. $\mathrm{sec}^{-2}$ on soft bottom and up to $100 \mathrm{~m} \cdot \mathrm{sec}^{-2}$ on hard substrate. Sweeping the accelerome- 


\section{crangon}

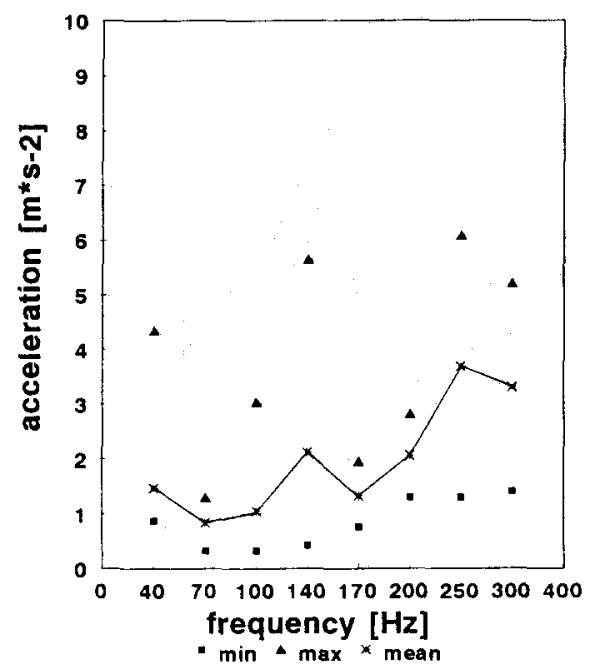

plaice

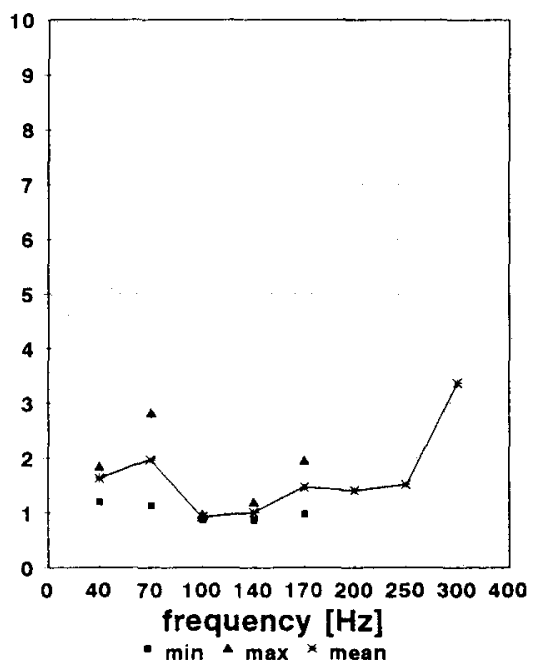

Fig. 4. Sensitivity of shrimp and plaice to sediment vibration. Water temperature $20^{\circ} \mathrm{C}$

ters with the rollers of a commercial shrimp gear resulted in a short pronounced signal of $24 \mathrm{~m} \cdot \mathrm{sec}^{-2}$ (Fig. 6). First signals of $6 \mathrm{~m} \cdot \mathrm{sec}^{-2}$ were recorded at a distance of $15 \mathrm{~cm}$ from the approaching rollers.

\section{DISCUSSION}

As for the rate of the behavioural reaction of Crangon to isolated stimuli of sediment vibration, vibration produced by the approaching rollers is unlikely to trigger tailflips in buried animals. Tailflips, however, are essential to get shrimps netted.

Stimulus response to sediment vibration observed in shrimp were the same as those recorded by Heinisch \& Wiese (1987). They consisted of reflex movements of antennules and antennae. Since an increase of the stimulus resulted in more pronounced movements of the second antennae up to burying, the reaction can be interpreted as hiding behaviour. The clear response to sediment acceleration at low frequencies (Fig. 4 ) is in agreement with the findings of Heinisch \& Wiese (1987) plotted in terms of displacement instead of acceleration. In Procambarus, sensitivity is also pronouncedly below $100 \mathrm{~Hz}$ (Breithaupt \& Tautz, 1990). Consequently, similar mechanisms of stimulus detection can be assumed. Antennal flagellae and sensory hairs are known to be hydrodynamic receptor systems in many crustaceans (Bleckmann et al., 1991). The latter are mainly located on the carapace, the telson, the paraeopods, and on the first and second antenna.

In plaice, vibratory stimuli caused one extra movement of the operculum. In case of an increase of the stimulus, burying behaviour could often be observed. For that reason, hiding intention can be assumed, as well. The same holds true for sole. This result corresponds with the hiding behaviour of sole in the field, when it is approached by a beam trawl (Berghahn, 1984). Lemon sole, however, seems to become alert when 


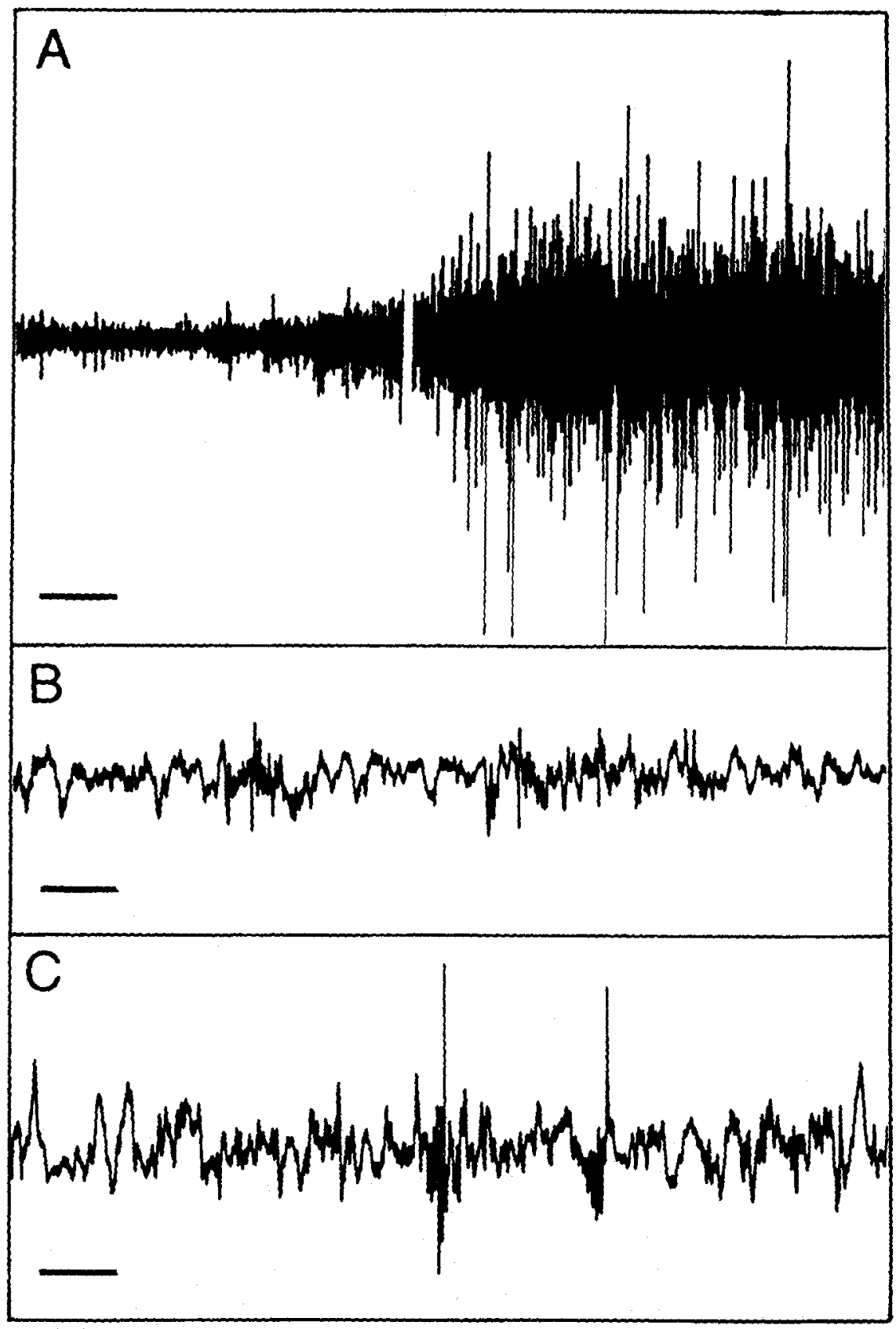

Fig. 5. Accelerations recorded by a meter attached to a roller of the roller gear in shrimping operation (Fig. 3). Weight of the roller $6.6 \mathrm{~kg}(2.5 \mathrm{~kg}$ in water $) . A=$ towing speed increased from 0 to 2 knots, bas $=3$ sec; $B=$ soft bottom, max. $40 \mathrm{~m} \cdot \mathrm{sec}^{-2}$, constant towing speed of 2.1 knots, bar $=$ $0.05 \mathrm{sec}_{i} \mathrm{C}=$ hard bottom, $\max .100 \mathrm{~m} \cdot \mathrm{sec}^{-2}$, constant towing speed of 2.1 knots, bar $=0.05 \mathrm{sec} ; 50$ to $500 \mathrm{~Hz}$ components 


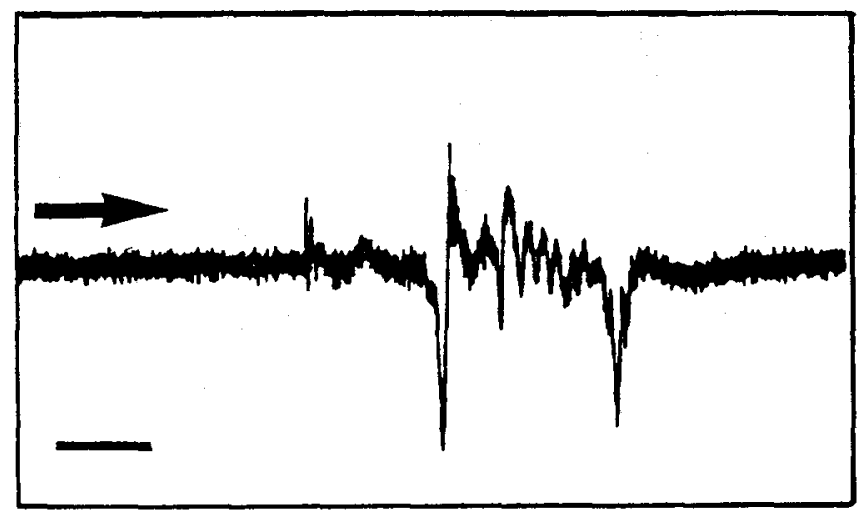

Fig. 6. Accelerations recorded by a meter which was buried on a tidal sand flat during low tide and swept with a commercial shrimp gear during high tide. Peak $24 \mathrm{~m} \cdot \mathrm{sec}^{-2}$; bar $=0.1 \mathrm{sec}$

stimulated. This is in accordance with the general observation from tank experiments, that lemon sole tries to avoid active gear by swimming over it, which is in contrast to plaice or flounder (Platichthys flesus L.). The thresholds for the sensitivity to sediment vibration reported here may be even lower in both shrimp and flatfish, if other than behavioural responses are considered. Nevertheless, these thresholds are two orders of magnitude below the peak signals recorded with an accelerometer in situ (Experiment 4). Moreover, no escape reactions, but only hiding behaviour could be induced by means of sediment vibrations in shrimp or flatfish, even if accelerations were increased by one order of magnitude.

In contrast to sediment vibration, water pulses can easily induce tailflips in both buried as well as emerged shrimp. This stimulus seems to have high priority in eliciting tailflips and in the catching procedure, respectively. If so, the stimulus and the alarm distance of an approaching gear can be expected to increase with towing speed. Stimulation of the trigger neurons of escape, the medial and the lateral giant neuron of the crustacean ventral cord, is under complex control of diverse inputs and inhibitions (Glantz \& Viancour, 1983). The inputs are mainly receptors on antennules and antennae (Wine \& Krasne, 1982). Stimulation can be greater in emerged than in buried specimens, since the escape reaction is inhibited in covered crayfish (Krasne et al., 1990).

Rollers which are commonly employed in commercial shrimping are $10 \mathrm{~cm}$ wide and $20 \mathrm{~cm}$ in diameter. Considering the slight rocking and jolting of the rollers when towed across the sediment, the rollers can be regarded as dipole sources of medium displacement (Wiese et al., 1980). From the acceleration measured at the axle of the roller in fishing operations at a towing speed of $1 \mathrm{~m} \cdot \mathrm{sec}^{-1}$, it is possible to calculate the underlying amplitude of roller jolting, assuming a dominant frequency of the spectrum of vibrations observed. If the peak value of acceleration, $b$, equals the amplitude of oscillation multiplied by $\omega^{2}(\omega=2 \pi \cdot f)$, the corresponding oscillation amplitude for $100 \mathrm{~m}$ $\cdot \sec ^{-2}$ acceleration at $100 \mathrm{~Hz}$ is $250 \mu \mathrm{m}$. Attenuation of this movement of the roller in the water can be described by the equation $d=A \cdot R^{3} \cdot r^{-3}$ (Van Bergeijk, 1967). The distance $r$ is measured from the centre of the roller; $R$ is the radius of the roller; $d$ is the water displacement measured at a distance $\mathrm{I}$ from the axle of the sphere. If the original 
oscillation of the roller is $250 \mu \mathrm{m}$ in amplitude, a point $5 \mathrm{~cm}$ in front of the approaching roller will be affected by a vibration with an amplitude of $d=250 \cdot 1000 \mathrm{~cm} \cdot 3375 \mathrm{~cm}^{-1}=$ $72 \mu \mathrm{m}$. This value is more than 2 orders of magnitude above the sensitivity thresholds for medium displacement in crustaceans (Procambarus $0.5 \mu \mathrm{m}$ : Tautz \& Sandeman, 1980; Euphausia superba $0.5 \mu \mathrm{m}$ : Wiese \& Marshall, 1990; Crangon $0.5 \mu \mathrm{m}$ : Heinisch \& Wiese, 1987; sensitivity to flow in Crangon antennules $0.5 \mathrm{~mm} \cdot \mathrm{sec}^{-1}:$ Lühr \& Wiese, 1990) and is probably apt to excite the lateral giant neuron to the level of spiking. Eliciting escape by a spring loaded piston at a distance of $5 \mathrm{~cm}$ could be achieved with accelerations down to $12 \mathrm{~m} \cdot \mathrm{sec}^{-2}$. In addition, a head is also produced by the small-meshed net (mesh size 11-12 mm; knot to knot).

According to fishing experience, Crangon catches increase with water turbidity or with decreasing light intensity. In the Wadden Sea, high catches can also be made during low tide, which Dahm (1975) attributed, on the basis of laboratory experiments, to the fact that Crangon is not buried during stow water, but is much more active in search of food. This interpretation, however, contrasts with the general finding that in areas with strong tidal currents an endogenous circatidal rhythm is established in Crangon with high activity around high tide and no activity around low tide (AI-Adhub \& Naylor, 1975). The high catches during low tide can rather be explained by the migratory behaviour of Crangon. A great part of the population in the tidal channels exhibits tidally-phased feeding migrations onto the submerged tidal flats (Berghahn, 1987). During low tide, the population is concentrated in a much smaller area, leading to higher catches.

The differences in the shrimp catches in the course of the tidal cycle, as well as during different light and turbidity conditions, can be explained as follows: given the average towing speed of a commercial shrimper of 2 knots (approx. $1 \mathrm{~m} \cdot \mathrm{sec}^{-1}$ ), even the observed distance of $10 \mathrm{~cm}$ for escape from the rollers approaching with 1 knot would be sufficient for Crangon $>4 \mathrm{~cm}$ in total length to avoid the gear, if the water is clear enough to detect the gear visually. This is because the beam is only 0.5 to $0.7 \mathrm{~m}$ above the bottom and shrimping has to be carried out with the current, which also supports the escape reaction of shrimps. Since the beam is ahead of the major part of the ground rope (Fig. 3), its visual detection may lead to an earlier escape reaction. Around high- and low-tide slack water, the escape reaction of shrimps is not supported by the current, since current velocity in the tidal channels and the main shrimping areas is close to zero. This may explain the higher catches around high and low tide even though water turbidity decreases during slack water. During low tide the catches are furthermore increased by higher shrimp densities in the subtidal due to tidal migration of shrimps from the tidal flats. In dark or turbid water, the escape reaction is not directed away from the gear, but in all directions, again yielding higher catches. Under such conditions, an additional groundrope which is rigged in front of the gear and acts like a snow-plow will chase away up to $60 \%$ of fish such as gadoids, smelt and clupeids without diminishing shrimp catches (Berghahn, 1993), even though the visual stimulus from the approaching net is the main factor for fish reaction and escape behaviour (Parrish, 1969). 0-group flatfish, however, in particular the small specimens which are not sufficiently sorted out by the selective shrimp trawl (Mohr \& Rauck, 1979; Berghahn, 1993), cannot be prevented from being caught with this gear modification, since they are herded in front of the gear and their swimming endurance as well as their burst speed is too low (Blaxter \& Dickson, 1959; Blaxter, 1969), Consequently, attempts to reduce the by-catch of small flatfish should 
focus on water displacement before the net as a means to make the gear more selective for shrimps.

In conclusion, (1) lower catches during the day and/or in water of low turbidity seem to result from shrimp escaping the gear due to its visual detection; (2) attempts to raise the selectivity of the gear should focus on displacement, flow and acceleration of water rather than sediment vibration.

Acknowledgements. Thanks to the fishermen Reinhold and Claus Herpel for their valuable support. This study is supported by the Federal Environmental Agency, Environmental Research Plan of the Minister for the Environment, Nature Conservation and Nuclear Safety of the Federal Republic of Germany (Grant 10802 085/01), and by the state of Schleswig-Holstein. This is publication No. 86 of the project Ecosystem Research Wadden Sea.

\section{LITERATURE CITED}

Al-Adhub, A. H. Y. \& Naylor, E., 1975. Emergence rhythms and tidal migrations in the brown shrimp Crangon crangon (L.). - J. mar. biol. Ass. U.K. 55, 801-810.

Bergeijk, W. A. van, 1967. Introductory comments on the lateral line function. In: Lateral line detectors. Ed. by P. H. Cahn. Indiana Univ. Press, Bloomington, 73-82.

Berghahn, R., 1984. Zeitliche und räumliche Koexistenz ausgewählter Fisch- und Krebsarten im Wattenmeer unter Berücksichtigung von Räuber-Beute-Beziehungen und Nahrungskonkurrenz. Diss., Univ. Hamburg, 220 pp.

Berghahn, R., 1987. The Wadden Sea as a nursery for fish and crustacean species. In: Proceedings of the 5th International Wadden Sea Symposium. Ed. by S. Tougaard \& S. Asbirk. National Forest and Nature Agency, Esbjerg, 69-85.

Berghahn, R. 1993. On the reduction of by-catch in the German shrimp fishery. In: Proceedings of the International Conference on Shrimp Bycatch. Southeastern Fisheries Ass., Tallahassee, 279-289.

Berghahn, R., Waltemath, M. \& Rijnsdorp, A. D., 1992. Mortality of fish from the by-catch of shrimp vessels in the North Sea. - J. appl. Ichthyol. 8, 293-306.

Blaxter, J. H. S., 1969. Swimming speed of fish. - FAO Fish. Rep. 62, 69-100.

Blaxter, J. H. S. \& Dickson, W., 1959. Observations on the swimming speed of fish. - J. Cons. perm. int. Explor. Mer 24,472-479.

Bleckmann, H., Breithaupt, T., Blickhan, R. \& Tautz, J., 1991. The time course and frequency content of hydrodynamic events caused by moving fish, frogs, and crustaceans, - J. comp. Physiol. 168A, 749-757.

Breithaupt, T. \& Tautz, J., 1990. The sensitivity of crayfish. In: Frontiers in crustacean neurobiology. Ed. by K. Wiese, W.-D. Krenz, J. Tautz, H. Reichert \& B. Mulloney. Birkhäuser, Basel, 114-120.

Dahm, E., 1975. Untersuchungen zum Nahrungserwerb von Crangon crangon Linné. - Ber. dt. wiss. Kommn Meeresforsch. 24, 105-133.

Glantz, R. M. \& Viancour, T., 1983. Integrative properties of crayfish medial giant neuron: steadystate model. - J. Neurophysiol. 50, 1122-1142.

Heinisch, P. \& Wiese, K., 1987. Sensitivity to movement and vibration of water in the North Sea shrimp Crangon crangon L. - J. crust. Biol. 7, 401-413.

Krasne, F. B., Vu, E. T. \& Lee, S. C., 1990. The excitability of the crayfish lateral giant escape reaction: inhibitory control of the lateral giant dendrites. In: Frontiers in crustacean neurobiology. Ed by K. Wiese, W.-D. Krenz, J. Tautz, H. Reichert \& B. Mulloney. Birkhäuser, Basel, 316-322.

Lüdemann, K., 1993. Fishery induced skin injuries in flatfish from the by-catch of shrimpers. - Dis. aquat. Org. 16, 127-132.

Lühr, B. \& Wiese, 1990. The antennules of the brown shrimp Crangon crangon as receptors for the velocity component of water displacement. In: Brain, perception, cognition. Ed. by N. Elsner \& G. Roth. Thieme, Stuttgart, 48 pp. 
Mohr, H. \& Rauck, G., 1979. First results of German experiments with a selective shrimp trawl. CM/ICES B7, 1-7.

Parrish, B. B., 1969. A review of some experimental studies of fish reactions to stationary and moving objects of relevance to fish escape processes. - FAO Fish. Rep. 62 (2), 233-245.

Tautz, J. \& Sandeman, D. C., 1980. The detection of water born vibration by sensory hairs on the chelae of the crayfish. - J. exp. Biol. 88, 351-356.

Tiews, K., 1983. Über die Veränderungen im Auftreten von Fischen und Krebsen im Beifang der deutschen Garnelenfischerei während der Jahre 1954-1981. - Arch. FischWiss. (Beih.1) 34, $1-156$.

Wiese, K. \& Marshall, H.-P., 1990. Sensitivity to vibrations and turbulence of water in context with schooling in antartic krill Euphausia superba. In: Frontiers in crustacean neurobiology. Ed. by K. Wiese, W. D. Krenz, J. Tautz, H. Reichert \& B. Mulloney. Birkhäuser, Basel, 121-130.

Wiese, K., Wollnik, F. \& Jebram, D., 1980. The protective reflex of Bowerbankia (Bryozoa): calibration and use to indicate movements of the medium beneath a capillary surface wave. $-\mathrm{J}$. comp. Physiol. 137, 297-303.

Wine, J. J. \& Krasne, F. B., 1982. The cellular organisation of crayfish escape behavior. In: The biology of the crustacea. Ed. by D. E. Bliss. Acad. Press, New York 4, 242-292. 